\title{
Humility and Glory*
}

\section{Rembrandt reads the Gospels}

\section{Esengrini S* \\ Università Cattolica del Sacro Cuore (Milan), Italy}

*Corresponding author: Dr. Stefano Esengrini, Università Cattolica del Sacro Cuore (Milan), Via G.B. Morgagni, 30 I - 20129 Milan, Italy, Tel: +390229536447; Email: stefano.esengrini@ virgilio.it

\section{Conceptual Paper}

Volume 4 Issue 4

Received Date: November 11, 2021

Published Date: December 06, 2021

DOI: $10.23880 /$ phij-16000206

For life, too, is only an instant, Only the dissolving of ourselves In the selves of all others, As if bestowing a gift. Boris Pasternak

\section{Abstract}

Through an attempt to move past both a historicist and a critical approach, this essay provides an interpretation of Rembrandt's gospel-themed paintings and engravings. Rembrandt's close interaction with the New Testament thus constitutes one of the speculative peaks with which the Dutch artist was able to give shape to the spiritual tension that leads man to confront the appearance of God. More precisely, the humble attitude that man takes on is the most intimate condition of possibility that man has to open up himself to what is 'other' in the name of a destiny that concerns each of us. From this perspective, Rembrandt's art opens a dimension within which man lives, insisting on it with that attitude of care capable of grasping the secret glory of all that is. Rembrandt's last religious paintings, together with the engravings consecrated to the Passion and Resurrection of Christ are the culminating manifestation of the attempt to give shape to the encounter between man and his experience of immortality.

Keywords: Rembrandt; Gospels; Existence; Truth; Humility and glory

\section{Homo Unius Libri}

Virtually ignored by specialists and unknown to the general public, Paul Baudiquey's work on Rembrandt's oeuvre is one of the clearest, where interpretation has been able to maintain a reasonable distance from both a historicist and a critical perspective. In fact, the four volumes that make up his contribution seem to have been motivated by a more radical spiritual need: that of fostering in the reader a new and more mature awareness of the truthfulness of a work of art and of its capacity to transform the meaning of our existence or, better still, of its very possibility. Rembrandt et la Bible (in two volumes), Vie et ouvre de Rembrandt and L'Evangile intérieur are the titles that make explicit, in a sort of ideal progression, the path that this French priest followed for more than twenty years, whose closeness to humble people did not preclude access to that realm of beauty which is how we usually identify the world of art. ${ }^{1}$

\footnotetext{
*This paper is the result of a four-year research project that benefited in the three-year period 2019-2021 from two residencies at the Centre for the Arts in Society and the Scaliger Institute of Leiden University. I thank Stijn Bussels, Kasper van Ommen, and Jef Schaeps for their invaluable collaboration and thoughtfulness in facilitating, in part through the provision of a Brill Fellowship, the consultation of the Special Collection of Rembrandt's etchings held in the University Library. Finally, I would like to thank Jeremy Hayne for his careful work in translating the manuscript from the original Italian version.

1 Cf. I. Donegani, Paul Baudiquey: fidèle aux Humiliés autant qu'à la Beauté, «Echos de Saint-Maurice», 1988, pp. 163-178; M.-L. Zurbriggen, Un évangile selon Rembrandt, «Echos de Saint-Maurice», 1990, pp. 81-90.
} 
However, we might want to question the wish to replace a method based on the more traditional art history and criticism with an approach that sees the demands of biblical exegesis accompanied by an aesthetic tailored to itself. For this reason, to dispel any doubts about this possible misunderstanding, it becomes necessary to go even further back in the experience of art through an in-depth examination of the relationship it has with our mortality. Because only death, beyond its reading in eschatological terms, is able to uncover the fundamental features of our existence, allowing us to get in touch with the most secret and authentic aspect of our being, before any profession of faith.

This is the starting point of an unusual essay with which Jean Genet, in 1953, wanted to explain the "indirect" effect of a Rembrandt retrospective on the perception of the self and the other, produced, very unpredictably, during a train journey. This was the origin of the extraordinary What Remains of a Rembrandt Torn into Four Equal Pieces and Flushed Down the Toilet, which was followed a few years later by The Secret of Rembrandt, a year after the decisive The Studio of Alberto Giacometti (1957), which Picasso called the best essay on art he had ever read. What aspect of man's mortality or, if you like, his finitude could ever be revealed in an anonymous train compartment? ${ }^{2}$

The subtitle of our paper leaves no doubt as to the theme we are going to explore. In the same way, Baudiquey's works confirm the impression that what is at stake in our study is the role played by the New Testament and, more specifically, by the Gospels in defining the possible relationship that man has with God through the intermediary of his son, Jesus Christ. $^{3}$

Leaving aside for the moment the reflection on the relationship between man's mortality and the figure of Christ - we will speak about this later in connection with Rembrandt's depiction of the celebrated episode of the agony in the garden of olives -, let's take a closer look at the last work by Baudiquey we mentioned, The Interior Gospel. After recalling that the work is divided into two sections dedicated to the study of two of the Dutch painter's most important works - The Hundred Guilder Print (1649) and his penultimate painting, The Return of the Prodigal Son -, we should point out that the very idea of defining the Gospel in terms of interiority demonstrates the conviction that the authentic nature of God cannot be grasped in the external world's phenomena, but first and foremost from the echo

\footnotetext{
2 J. Genet, Rembrandt, «l'arbalète», Gallimard, Paris 2016.
}

3 Cf. W. Sumowski, Rembrandt erzählt das Leben Jesu, Evangelische Verlagsanstalt, Berlin 1958 (in part., Nachwort, pp. 162-173); ID., Das Leben Jesu in Bildern, Handzeichnungen, Radierungen von Rembrandt, EckartVerlag, Witten/Berlin 1963. of his appearance in man, who would become, so to speak, God's guardian and first witness.

At this point we only need add a third fundamental piece of knowledge, which furthers this very "immanentist" conception. We refer to Rembrandt's particular attention to the so-called «Pauline theology», which led him on more than one occasion to portray himself as St. Paul and to dedicate at least two of his last paintings to the Saint. ${ }^{4}$ A choice that has certainly been discussed in the now vast secondary literature, but has never been traced back to its original foundation, to the point of becoming the inspirational motif of Rembrandt's entire oeuvre or, at least, of his mature phase, which began in 1642 with the death of Saskia, his beloved first wife. The names of Baudiquey and Genet are now joined by those of John Henry Newman, better known as Cardinal Newman, and Pier Paolo Pasolini, the former the author of a number of sermons and the latter of a screenplay for a film (never made), who stand out for the lucidity and intensity with which they were able to draw us closer to the figure of St. Paul and the meaning of his apostolate. ${ }^{5}$

Let us begin our work with a consideration taken from the first section of the Interior Gospel, which already in its title - A Gospel According to Rembrandt - shows how Baudiquey (and Vincent van Gogh before him) considered the painter to be the fifth evangelist. Unlike the first four, the painter chose colour and line as the way to spread the Good News and to confer truth - through a drawing, engraving or painting - on man's meeting with his God. This encounter is based on a way of thinking that harmonises Rembrandt's work from top to bottom and presents God not as empty dogma but as an intimate necessity for man. Because no dogma could ever justify the fact that 145 canvases out of 650,70 etchings out of 300 and 570 drawings out of 12501500 have a biblical subject as their theme. No dogma could ever justify the profound influence the Bible exerted on him, which earned him the nickname «homo unius libri». Now, is there a thought worthy of a relationship with the divine that goes beyond any faith-based stance, that does not require any adherence to a particular Church or to a privileged confession (it doesn't matter even if it were the Mennonites), and that therefore does not make Rembrandt a "religious painter" in the narrow sense of the term, but a mystical spirit inhabited by the voice of heaven that resonates in him?

4 Cf. Rembrandt's Late Religious Portraits [catalogue], National Gallery of Art, Washington 2005, pp. 74-77, 82-84 and 108-110; Rembrandt: The Late Works [catalogue], National Gallery, London 2014, pp. 215-233 (Contemplation) and 253-269 (Reconciliation).

5 J. H. Newman, San Paolo, Castelvecchi, Rome 2019; P. P. Pasolini, San Paolo, Garzanti, Milan 2017. 


\section{Philosophy International Journal}

\section{The Identity of All Men}

Our theory is that the first section of the Interior Gospel can be summed up in a single sentence, which appears for the first time in the paragraph dealing with some very valuable observations on engraving techniques: «Only humility leads to glory» ${ }^{6}$

This humility is also found in the two essays by Jean Genet, in the fourfold portrait of St. Paul proposed by Cardinal Newman, but above all in Rembrandt's own life, following the death of Saskia, which led to a slow but progressive withdrawal from public life in the shadow of the thought of being nothing more than a poor man among the poor.

In the same way, this "sensitivity" towards other men enabled Rembrandt-Paul, as the first sinner, to take on the task of leading to salvation the different communities he encountered during his wanderings. Not because he was superior, but on the contrary, based on him recognising the need to search for meaning, which he felt he lacked more than anyone else! Hence the insistent attention paid to the figure of the beggar, whom Rembrandt - partly based on Roger Callot's teaching - portrayed in all his poverty and desolation. In this way, a phrase by Charles Péguy quoted by Baudiquey (p. 80) allows us to instantly grasp the fulcrum of Rembrandt's entire oeuvre and, with it, of man's existence in the name of that «universal identity of all men» on which Jean Genet would vigorously insist. The poet, who was the honour of France and author, among other things, of a shocking Gethsemane, on which we shall focus on in our final lines, wrote:

It is the person who begs, whoever they may be, whether the beggar wandering along the road, the blind man in wretched conditions, the outcast, the defeated, the helpless old man, the orphan, the woman without a dowry, in short, it is always the person who begs who occupies the noble part of the dialogue. The stranger comes from the gods. The unhappy person is an emissary of the gods.

Far from being destructive, unhappiness offers a privileged opportunity for each of us to experience our own finiteness and to bring about a change based on the renunciation of the self as a requirement for all dialogue, as well as for every act of thanksgiving. To become aware that what is other than oneself has equal dignity triggers that revolution of the gaze that becomes capable of welcoming and recognising the other as an identifying element of one's own self. This is why Jean Genet, just a few years after the first of his two essays on Rembrandt, was able to recognise the profound affinity between the great Dutchman and a

6 P. Baudiquey, Un évangile selon Rembrandt, Mame, Paris 1989, p. 44. second royal loner, Alberto Giacometti, who - as the sculptor himself relates in the course of a legendary conversation with Pierre Schneider - one day realised that he had to turn his gaze away from the film projected onto the screen and place it on something that would provoke totally unexpected amazement: the spectator himself! ${ }^{7}$

This simple shift of focus proved capable of overturning the entire modern metaphysical tradition, where the subject was the cornerstone of the system of subjugation with which man had been able to put the entire world at his disposal as a real target. The figure of the subject can thus be contrasted with that of the child or, more precisely, of the naïve person as the one who, in his naivety to the world, «will take me by the hand» - wrote Georges Bernanos - «at the moment when I shall enter into God». And again: if putting the subject in brackets allows the world to reveal itself, it is not surprising that Van Gogh also noted that one cannot see a Rembrandt without (ending up) believing in God.

Let us therefore abandon any historicist or aestheticist claim, and instead reserve all our hopes of understanding the work of art to the method that follows the thread of existence as a "testing ground" of the truthfulness with which the work indicates the essential in what is. With this in mind, it seems appropriate to consider some of the topoi of Christ's life, repeatedly chosen by Rembrandt as icons capable of demonstrating to man - on the basis of the divine model - a possible way of living in communion with what is above us, but to which we are in no way extraneous.

Among the possible avenues of research highlighted so far, a closer examination of the figure of St. Paul as «apostle to the people» is obligatory. To this end, we have identified two essays that will allow us to examine the extent of the thought and actions of the man who, as a faithful observer of the Jewish religion, was guilty of the grave sin of having contributed to the persecution of Christians. As the Gentile he had been (before his conversion), he could say of himself that he had acted before God in full rectitude of conscience. For this reason, the thunderbolt that struck him on the road to Damascus is even more decisive, insofar that it marked the beginning of that inner revolution that allowed the apostle to become a spokesman for Christ's words with a "persuasive" capacity that was increased precisely by the recognition of his own inherent misery.

To the four sermons preached by John Henry Newman between 1831 and 1857 can be added the script of a film by Pier Paolo Pasolini about St. Paul, whose main merit consists in recognising that «St. Paul is here, today, among us» - testifying to the opening fact that, «even in a world of

7 A. Giacometti, Écrits, Hermann, Paris 2007, pp. 231-232. 


\section{Philosophy International Journal}

steel and concrete, God's word has resonated (or resonates anew)» (p. 20). In other words, Pasolini's choice to interpret Paul's experiences in a modern key is nothing other than an attempt to re-establish that dialogue between man and God which alone is capable of allowing the re-emergence of the possibility of a world where man can build his own house, or rather, can find his own roots, which is the original need of every individual and every historical community - of every community capable of producing its own history within the space-and-time opened up by the destiny announced by Nietzsche with the «death of God».

In this way, the study of Rembrandt's paintings and drawings loses all antiquary traits, and once again becomes an opportunity to listen to the words of the conversation with the divine that awaits future humanity, when it will be able to bring back within its own limits the claims made by all forms of scientism in favour of the emergence of the poetic-mythical word, which requires nothing and indicates everything.

(It is beyond the scope of this paper to study the ways in which contemporary art supposedly planned, in unprecedented ways, the appearance of a space-and-time which favours the emergence of the sacred or of the world, whose aspect is defined by the contrapuntal play of men and gods, earth and sky. How else can we interpret the Rothko Chapel in Houston or Tadao Ando's Church on the Water?)

Moving on, let us make one of Newman's phrases our own and point towards the heart of the Pauline adventure. Emblematically, the Cardinal wrote (p. 76):

In St. Paul the fullness of divine gifts does not tend to destroy what is human in him, but to spiritualize and perfect it.

The spiritualisation, or rather, the perfecting of man, does not assume that the human feature disappears, but, on the contrary, allows it to shine in accordance with its most authentic possibilities, transfiguring the limits of man as mortal into a privileged place where the vastness to which we are exposed resounds. If, in fact, to quote Martin Heidegger, «around man reigns the Open», man's finitude is the echo of a dimension in which we must be able to take root, without, however, having the pretension of defining and circumscribing, but by listening to and responding in unison to a grace that permeates all aspects of our behaviour and leaves us quivering with a richness of which we are not masters, but careful sharers. As Paul wrote in his First Letter to the Corinthians (15:9-10):

I am the least of the Apostles [...] by the grace of God I am what I am: and His grace which was bestowed upon me was not in vain; but I laboured more abundantly than they all: yet not I, but the grace of God which was with me.

Placed at the beginning of the first sermon entitled The Conversion of St. Paul viewed in Reference to his Office (January 25, 1831), this phrase begins Newman's reflection by clarifying its tone and its underlying question. We are amazed to learn that finitude is an opportunity for man («strength is perfected in weakness»), since we should not read in it an absence, but the faint glow of that grace that God grants to man's fragile existence. Grace that, let it be said again, transfigures our every thought and action into an indication that matches the lightness of the divine flagrancy, its omnipresence that invites everything to be part of it. Regarding the saint and his aim of pleasing and obeying God, Newman teaches us that the saint is not only gentle, but meek; not only generous, but humble; not only persevering, but patient; not only upright, but forgiving.

Are not Christ, and with him Paul, those who point towards that sense of wholeness that is echoed in the tenderness with which man imitates the making of space in the world in the interplay between men, gods, earth and sky? Are not meekness, humility, patience and forgiveness the signs of a fullness that is such not because of its power, but because of that intimacy that alone knows how to return to the origin of what is and that shows it, even in its fragility, as something whole and intact?

\section{Beyond Aesthetics}

Let us slow down and explain the principles of the method we have adopted, insisting on the difference between an approach that listens to the work of art and one that aims to explain its meaning through an extensive collection of verified and verifiable data. In fact, there seems to be bitter criticism from many quarters of the work of those who venture down unfamiliar paths, basing their work on the perception or awareness of something that eludes measurement and that, rather, anticipates it, by offering an interpretation of the work that is not based on its proportions, the technique adopted or, worst still, the author's psychology.

The worrying sensation of loss and loss of balance felt by those who rely on a historicist approach is nothing but the last legacy of a cognitive attitude that prefers to acquire the necessary information before proceeding to their interpretation. And yet we are talking about a leap here - a leap that cannot be broken down into its different phases, having in its rapidity and immediacy the element that distinguishes it and, at the same time, allows us to be in direct contact with the thing we are looking for, beyond and before any demonstration, being with it right from the beginning in an enigmatic familiarity. If, in fact, there is no 
separation between man - his actual self - and the world, it only remains for us to postulate a condition of primordial openness that establishes the possibility of a relationship between a subject and its object.

In other words, beyond and before any objective knowledge something is offered as a meaning that allows man to be part of what he experiences, and not just its judge. Thus, the work of art, far from being a product of man's desire to represent his world, is the response with which man confronts an invitation - an invitation whose appeal he hears every day and which he translates into his mother tongue in the form of an indication that allows him to venture into the unknown. Therefore, to accuse such a way of proceeding as being unfounded means not having perceived the fathomless nature of the basis of everything, which is so insofar that it is itself without any reason why.

It is up to us to safeguard the nature of this enigma that is art itself and to prepare for that listening to the poetic word that will know how to initiate a new way of speaking and being together on this Earth - that is, within a space-and-time where what prevails is the coming together of what is in the instant where a world begins to take shape. For this reason, Paul Baudiquey's suggestion that Rembrandt gave shape in lines and colours to the same experience of the sacred that was later sung by Tolstoy, allows us to approach each of his paintings or drawings with the awareness of encountering not the copy of something real, but the trace of a memory that it preserves.

Caught between the secret of his origin and his revelatory apparition, the figure of Christ portrayed by Rembrandt in the splendid Noli me tangere of 1655-1656 presents us with the Risen Christ surrounded by an aura that shows his nature as pure spirit. In this case, the evanescence reveals itself as the most appropriate indicator of a thought that goes beyond representation, to reveal the threshold that separates and unites the human and the divine. ${ }^{8}$ In all of this is not humility the human trait most conducive to letting everything appear in its discreet glory?

Let us go deeper into the figure of St. Paul starting with what Cardinal Newman defines as «his characteristic gift», or rather, that character trait that allows us to understand the origin of the process that led Rembrandt to identify himself with the apostle. It is not by chance, then, that the third sermon, delivered on January 25,1857 , has a sentence in the preface that insists once again on the limits of man:

Gladly therefore will I glory in my infirmities, that the

8 O. Benesch, Rembrandt as a Draughtsman, Phaidon, London 1960, Plate 80. power of Christ may dwell in me.

The Saint continues:

Therefore I am content with weaknesses, insults, hardships, persecutions, and calamities. For whenever I am weak, I am strong.

It is noteworthy that Newman interprets this thought starting from a famous motto by St. Philip Neri: «I am without hope». In other words: it is in the renunciation of the self where the possibility of realizing oneself in accordance with what destiny has handed to us lies. Christ himself, whom Rembrandt takes care to present to us as a man before being a god, embodies the tension that exists between the human and the divine by experiencing death and passion, even being slapped in the face - as François Mauriac (Le visage du Christ) reminds us - by the High Priest's servant just before being scourged.

Empty yourself until you identify with a dog: this is how Giacometti came to perceive the person that each of us is in our own intrinsic solitude, that is, when we experience the universal identity of all beings, here caught in the nakedness of their presence, in their shared response to a dimension that escapes all our attempts to calculate and control. Giacometti's dog, as Rembrandt's beggar, is nothing but the indicator of the need to reawaken in every man that thought of humility that can only be found in those who have an inkling of the secret glory that awaits each of us. Preparing ourselves for glory then becomes that wholly spiritual revolution that can find a renewed sense of rootedness which alone can establish an authentic hierarchy-less equality, since it is made possible by the shared call to face a destiny that summons each of us to leave our own specific mode of humiliation.

In this sense, the moments of desolation, degradation, and poverty do not aim at destroying man, reducing him to something insubstantial and expendable, but, on the contrary, at sowing in the heart, of even the smallest things, the seeds of a new birth, of a morning in the world which, even in the fragility of its dawning, anticipates and makes palpable the vastness of man's encounter with the entire world. A world tuned to decorum is what we can expect from those, like Rembrandt or Tolstoy or Shakespeare, who thought about that dimension of intimacy that animated the most touching Adoration of the Shepherds (1654) or the embrace with which a young mother, like Mary, cradles her child, giving shape to a space that we call "sacred family» and from which the father himself is almost excluded, and portrayed in The Virgin and Child with Cat and Snake (1654) behind a window, reduced, with us, to the role of enchanted spectator. Similarly, the vivid image with which Rembrandt was able to render The Stoning of St. Stephen (1635), with the 


\section{Philosophy International Journal}

third murderer preparing to grab yet another stone (perhaps the fatal one!), lets us perceive, albeit silently, the incredible prayer by the martyr for God to forgive his murderers or brings to mind the testimony according to which Stephen, shortly before his death, saw the heavens open with Jesus sitting at the right hand of the Father.

The only thing missing from the careful and charitable interpretation offered by Paul Baudiquey of The Hundred Guilder Print, followed by an equally masterful reading of the painting depicting The Return of the Prodigal Son, is a judicious analysis - in the wake of what has already been proposed by Max Milner - of the celebrated Supper at Emmaus, reprised by Rembrandt no less than nine times (between oils and engravings) and which had its dramatic and figurative climax in the contemporary and subsequent versions of the one painted in 1648, today housed in the Louvre. Is it not time, at this point, to pay particular attention to the expression attributed by Rembrandt to the very face of the Messiah, the locus par excellence of the epiphany that is the encounter and transfiguration of man in God and God in man? ${ }^{9}$ Finally, what can we say about the many versions (we know of at least five) of the Agony in the Garden (1657), where the angel helps Christ who, about to be captured, is distraught at the thought of what awaits him, never being so close to the human condition as at that highly tragic moment? ${ }^{10}$

\section{A Secret Regality}

Everything is now ready to discuss the aforementioned essay by Jean Genet, from which shone the first light able to illuminate our painter's vibrant work.

We'll repeat it: Genet actually dedicated two texts to Rembrandt and, more specifically, they are related to an event that made history in the existential life of the poet. In fact, in 1953, at the same time as seeing one of Rembrandt's solo exhibitions in Amsterdam, Genet had a chance encounter that nonetheless indelibly marked his path as a man and artist. What's more, this was such an important episode in his life that it was taken up in the extraordinary 1957 essay on Alberto Giacometti, which has the merit of tracing the hidden origin of the work of one of the twentieth century's artists who, more radically than any other, tried to come to terms with the future status of figurative art. How else can

9 Cf. Rembrandt et la figure du Christ [catalogue], Musée du Louvre, Paris 2011; V. A. Visser 't Hooft, Rembrandt et la Bible, Delachaux et Niestlé, Neuchâtel and Paris 1947, p. 19.

10 For a genealogy of this subject in Rembrandt's work, we refer the reader to the analyses conducted by Christopher White in his well-documented Rembrandt as an Etcher, Yale University Press, New Haven and London 1999, pp. 108-112. we interpret his choice to concentrate all his efforts on the rendering of the head - that is, on the truth of the gaze - of a man?

Let us start at the end and quote a phrase by Genet on Giacometti and, more precisely, on the sculpture that depicts a dog in the deserted streets of a ghostly Paris. Genet wrote:

Solitude, as I understand it, does not imply a wretched condition, but rather a secret regality, a profound incommunicability and at the same time a more or less obscure awareness of an unassailable singularity.

If we hold onto the fact that this sentence concludes a paragraph that started with the following words:

It is this secret region, this solitude in which beings - and things - take refuge that makes the road so beautiful -,

we need to understand how a clarification of the aforementioned solitude will allow us to have a more pertinent idea of what beauty is and how beauty, contrary to what is commonly believed, can be found almost anywhere - for example, on the road, or in a place apparently so impersonal that what it holds most secret and dear is neglected. In other words: what type of revolution of the gaze must a man have experienced so that "even" a road contains a treasure of beauty, that is a trace of royalty - here to be understood in terms of singularity, or rather of irreplaceability?

Now we come to that episode on the train which is the starting point of the first of the two essays dedicated by Genet to Rembrandt and which plays such a large part in the second, The Secret of Rembrandt, which presents itself as the synthesis of what was more directly expounded in the first, more "original", attempt to share a perception at the limits of hallucination, which, if grasped, is nevertheless capable of reconciling man with his own possibilities. We refer to a thought that finds expression in a phrase that we used in the first pages and that sounds like: «a sort of universal identity common to all men». Said differently: «every man is the equal of another» or, according to a very effective formulation, which still needs to be clarified: «every man [is] what every man is».

(It is worth mentioning here, on an intuitive level, the examples suggested by Genet regarding the beauty of the street - the one hundred and fifty lithographic pencil drawings by Giacometti, later included in Paris Without End, come to mind by association:

A thin and very tall, hunched man... an imposing housewife... an old man who is not a handsome old man... a solitary tree... a clerk, another...) 
This perception of identity or identification is the same that lies at the heart of our feeling of being brothers! But what does it mean that «each man is all the other men»? Genet glosses this in the meantime as «Each one of us is the other and the others». And again:

No man was my brother: every man was myself, but temporarily isolated in his own unique skin.

To all this we must add that this sequence of thoughts only provoked in Genet a feeling of sadness that disturbed him: in fact he felt that by now «the world had changed». In other words, the world seemed to have lost its beautiful colours, causing the poet to feel that he was heading towards an increasingly lonely future that generated «discouragement». «Soon nothing will matter to me anymore», Genet emphasizes, confirming the doubt - which had always plagued him - that the world has never had (and still does not have?) its own wholeness (the word in the original French is in italics!).

But this experience also reveals itself capable of laying us bare and ripping open our appearances, which in the end only conceal that «solid void» which each of us is. And it is precisely at this point that Genet calls upon Rembrandt to speak up, accusing him of «having removed every embellishment» and thereby highlighting our «infinite, infernal transparency». A transparency that puts an end to any feeling of power deriving from single individuality, or that is strong in its singularity or uniqueness (uniqueness that in Genet's terms translates into «eroticism», which is why this experience of universalist identification would seem to deny once and for all «eroticism and its lusts»). A transparency, as the word itself suggests, that reveals a higher idea of man and, with it, that impression of «confident strength» which, according to Genet, Rembrandt's paintings convey.

In this way, leaving behind the taste for pomp that had characterized his life before the death of Saskia, Rembrandt was able to avoid the risks of a sterile virtuosity in favour of the intensity with which things are displayed in all their magnificence within that space-and-time that we all share and which we call the "world". It is only after having regained this idea of the world that the divine - for us, the figure of Christ - can serve as the polar star of our journey, embodying in the figure of the "good Father" that thought of forgiveness, or rather of thanksgiving and charity, which Rembrandt came to paint at the end of his life, in which each of us can now recognize ourselves and with which we can finally be reunited.

\section{Art and Space}

Preparing for a possible encounter of man with God, even before adopting one religious confession or another, is what the Russian poetess Ol'ga Sedakova proposes to do in her book dedicated to Rembrandt and which comprises eight letters addressed to the philosopher Vladimir Bibichin. In it, she firstly gives voice to what is called «biblical space», to which the origin of the Dutch painter's work - and, except for the biblical connotation, of every creative genius - can be traced, insofar as it names, in the first place, the appearance of reality as it is, and not the dogmatically predefined space of Judaeo-Christian reality. ${ }^{11}$

In fact, it is no coincidence that the phenomenon of biblical space is clarified by Sedakova herself in the context of the idea of «field», which is understood in turn as a sphere of action definable in terms of «vital impetus» or «warmth», within which things take on life and shape and unfold as manifestations of a single principle which the poet, in the case of Lazarus, calls the «force of resurrection»; in the case of the Prodigal Son the "force of blessing»; and finally in the case of Simeon, the «force of loyalty and fulfilment of a promise». Therefore, these three apparently distinct forces, are the children of a single need, for which «life has the quality of a question, of a prayer» - both in Rembrandt as well as among us today.

Rembrandt's works thus take on an initiatory value, not so much for the fact that they adequately represent this or that biblical episode, but because they open up that «vastness» or horizon in which the individual episodes do not limit themselves to merely recording a fact, but - in the words of Boris Pasternak - notify something «not so much in the light of everyday life», but first and foremost «at the level of immortality». In this sense, the culminating figures of Simeon and the father of the prodigal son, as they were conceived by Rembrandt in the last year of his life, address us with the same immediacy and capacity for penetration as the mummy portraits of Fayūm.

In fact, these latter, in their intense frontality have the aspect that allows them to become, first of all, icons of an opening of space-and-time that allows things to enter into presence and to be approached by those who are attentive to them! This is the world whose last word will never be uttered, since its crowning glory is found in perpetual renewal. Is not then the good news of the Gospel, like every other essential word, marked by the care of the simple as that which preserves the fervour of the inconspicuous? Emily Dickinson wrote in a message to Mrs. Frederick Tuckerman in June 1884:

11 O. Sedakova, A Travel with Eyes Closed. Letters about Rembrandt, Limbakh, St. Petersburg 2016. I would like to take this opportunity to thank Giovanna Parravicini, who kindly made her translation from Russian available to me. 


\section{Philosophy International Journal}

Let me commend to Baby's attention the only commandment I ever obeyed - «Consider the lilies». ${ }^{12}$

Given the near-invisibility of the dimension where man and his God meet, it is not surprising that the title of Ol'ga Sedakova's work refers to a Journey made with one's eyes closed and this, for the very reason that very blindness is no limit to the sighting of that «superhuman infinity» - as Van Gogh called that space dear to Rembrandt - in which we happen to feel a presence beyond mere facts.

It goes without saying, therefore, that the seeing that the poetess speaks of, and which we can experience every time we find ourselves in the presence of great art, is not just about noticing something, but is able to present it thanks to a sort of sixth sense that anticipates the possibility of its presence. In the same way, space - biblical, in Rembrandt's case - is not reduced to the total number of the plentiful religious subjects he reproduced from time to time. To put it another way: the various paintings, drawings or engravings that present this or that episode from the Old or New Testament are not the faithful transposition of the biblical text, but are the indication of the possibility in and the meaning of that episode - an indication that does not prevent the episode from lending itself to a new interpretation, but always in the form of an instantaneous glance that opens up, or rather allows, a space-and-time to begin that heralds a world and that, precisely for this reason, makes that episode revelatory.

There is more: the fact that the work is not a copy of an actual event leaves the interpretation of its origin open, which then appears here in all its enigmatic nature. Ol'ga Sedakova's journey is therefore made with closed eyes to remind us that in painting the essential is not found in what we see, but in what we feel. For this reason, the first thing - but chronologically it is the last to be felt - is that life has the nature, we would add, of a gift or a thanksgiving. Thus the Rembrandtian icons of the Agony in the Garden, the Crucifixion and the Supper at Emmaus could not have better made us experience the vastness of the world and its inviolability by announcing Christ's humanity, the transfiguration of death and the new world under the banner of the Resurrection.

These are the three archetypes to which the most genuine possibility of an existence in communion with the divine is given. The freedom (or free space) established by these three icons makes our stay on Earth finally true - we repeat: only humility leads to glory. This is the dominant thought of a world in harmony with the sacred, where the work of art responds to the opening up of the world that claims every man by revealing itself in its need. The timeliness of the

12 T. H. Johnson (ed.), The Letters of Emily Dickinson, Harvard University Press, Cambridge (Mass.) and London 1986, p. 825. decision with which man faces the vastness of the world also corresponds to the need to interpret the work of art by going beyond any procedural or technical explanation in order to expose ourselves to the risk of what we do not know. Only a similar attitude towards everything that is knows how to welcome the work of art with that awe that wonders how it could ever have come to exist.

What intimate existential urgency does the work respond to in its originality? To what need does the departure from the portrayal of a work of art correspond, that is in search of the person who makes it happen? Is it not the work and its composition that makes its creator true? Where does truth dwell, so that it can be given form?

According to Van Gogh, that "glimpse of superhuman infinity» which distinguishes Rembrandt's work is accompanied by that feeling of «afflicted tenderness» that sees its most secret manifestation in the episode of the agony in the olive garden. ${ }^{13}$

More specifically, in the context of the idea of a communion between men and God, we can say that in the topos of the agony in the garden we witness the transcending of every hierarchy. In God's becoming man, a pact is made which transfigures their respective essences - a pact which brings God back here to earth, so that earth in turn can rise to heaven and spiritualize man.

The extraordinary fact is that Christ himself had a firsthand experience of his being a man, trembling before the fulfilment of a destiny that wants him dead on the cross. This is what Charles Péguy was referring to in his Gethsemane, a work contained in Véronique. Dialogue of History and the Carnal Soul and which remained unpublished at the time of his death. Christ, in fact, would not have been a real man, that is, a man through and through, if he had «ignored, not tried, refused to try man's greatest terror», his greatest «misery». Thus Péguy makes Christ say - and it is here that we touch the core of biblical space - that his subsequent arrest and his appearance before Pilate «are nothing, it is just the procedure». Because the decisive meaning of the Passion is death itself, «the common death», that is, the fact of dying, even on a bodily level. Because, if the spirit is ready (to die), it is the flesh that is weak - in man, and now also in God!

Helped by the angel shortly before accepting his destiny, Jesus bends to the will of the Father, consenting at a distance of five thousand years to the fiat lux of Genesis: in the fulfilment of the Father's will, Christ responds to the creation of the universe with his own creation. Everyone was awaiting this

13 V. van Gogh, Letter to Theo, 2 July 1889 (cf. http://vangoghletters.org, no. 784). 
second creation, already inscribed in the first, but Christ took his time and, «though at the end he obeyed, for an instant he wavered». An instant that ushers in the world in which we are rooted, exposed as we are to an abyss that even shakes a God, and that also claims us. Complying with the destiny of the universe: this is our fathomless freedom. In this sense, preparing to die is the lesson we learn from the confidence with which Simeon, even in his blindness, presents the one who will save the world, or rather for us, that space in which men and gods can make their appearance - or at least that space in which a measure is given to our existence that breathes the vastness of the cosmos. There perhaps we will be reached by a word that will free us. There, perhaps, we will be able to pay homage to the glory that lingers in all things and - by the very fact of being - celebrate our union with all others. With eyes closed.

\section{Christ's Presence}

The adoption of an existential-phenomenological approach has shown the need to move beyond aesthetics as the method used by the metaphysical tradition to interpret a work of art, inducing us to embark on a new path to access art and its truthful power. Even before being reduced to representing something real, the work of art seems to draw its founding instance from an indefinite dimension. However, such vagueness should not be understood as a manifestation of impotence or inconsistency, but, on the contrary, it reveals itself to be the element that favours the appearance of each being caught in its possibility. This is the space that Ol'ga Sedakova referred to in her essay on Rembrandt - an essay, in fact where the Russian poetess prepared our gaze for our entry into Christ's presence as a figure capable of illuminating with his own sacrifice the profound sense of all humility, i.e. the authentic glory of what is.

On the basis of this singular perception, the work of art is not a mere copy or imitation of what exists, but conveys its living incandescence, its most intense splendour, its secret taking place. From this perspective, the aesthetic conception of the work of art reveals the limits of the interpretation of the world as an object that is opposed to a subject that judges it, that occupies with its explanatory claim the space-and-time dedicated to splendour, transparency, to the revelation of Being. A revelation, however, which reaches its culmination in that mystery which appears to prefer contemplation and silence and which sees in the poverty of what is small the traces of an overabundance that is bestowed with discretion.

This is the origin of the spiritual light within which the thought of that universal identity of all men can take shape and which was experienced, on one hand by Jean Genet and Alberto Giacometti, and on the other by Rembrandt respectively in the streets and squares of Paris or in the lanes of the Jewish quarter of an Amsterdam where the Dutch painter was able to recognize among the faces of ordinary men the features of the Son of God. 